\title{
Regional effects of vegetation restoration on water yield across the Loess Plateau, China
}

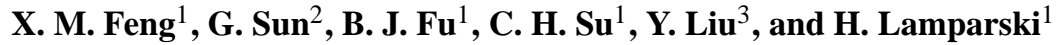 \\ ${ }^{1}$ State Key Laboratory of Urban and Regional Ecology, Research Center for Eco-Environmental Sciences, \\ Chinese Academy of Sciences, Beijing 100085, China \\ ${ }^{2}$ Eastern Forest Environmental Threat Assessment Center, US Department of Agriculture Forest Service, \\ Southern Research Station, Raleigh, NC27606, USA \\ ${ }^{3}$ College of Global Change and Earth System, Beijing Normal University, Beijing 100875, China
}

Correspondence to: X. M. Feng (fengxm@rcees.ac.cn)

Received: 14 March 2012 - Published in Hydrol. Earth Syst. Sci. Discuss.: 29 March 2012

Revised: 11 July 2012 - Accepted: 18 July 2012 - Published: 10 August 2012

\begin{abstract}
The general relationships between vegetation and water yield under different climatic regimes are well established at a small watershed scale in the past century. However, applications of these basic theories to evaluate the regional effects of land cover change on water resources remain challenging due to the complex interactions of vegetation and climatic variability and hydrologic processes at the large scale. The objective of this study was to explore ways to examine the spatial and temporal effects of a large ecological restoration project on water yield across the Loess Plateau region in northern China. We estimated annual water yield as the difference between precipitation input and modelled actual evapotranspiration (ET) output. We constructed a monthly ET model using published ET data derived from eddy flux measurements and watershed streamflow data. We validated the ET models at a watershed and regional levels. The model was then applied to examine regional water yield under land cover change and climatic variability during the implementation of the Grain-for-Green (GFG) project during 1999-2007. We found that water yield in $38 \%$ of the Loess Plateau area might have decreased $(1-48 \mathrm{~mm}$ per year) as a result of land cover change alone. However, combined with climatic variability, $37 \%$ of the study area might have seen a decrease in water yield with a range of $1-54 \mathrm{~mm}$ per year, and $35 \%$ of the study area might have seen an increase with a range of $1-10 \mathrm{~mm}$ per year. Across the study region, climate variability masked or strengthened the water yield response to vegetation restoration. The absolute annual water yield change due to vegetation restoration varied with pre-
\end{abstract}

cipitation regimes with the highest in wet years, but the relative water yield changes were most pronounced in dry years. We concluded that the effects of land cover change associated with ecological restoration varied greatly over time and space and were strongly influenced by climatic variability in the arid region. The current regional vegetation restoration projects have variable effects on local water resources across the region. Land management planning must consider the influences of spatial climate variability and long-term climate change on water yield to be more effective for achieving environmental sustainability.

\section{Introduction}

China's Loess Plateau region stretches a total area of 0.64 million $\mathrm{km}^{2}$, and drains the upper and middle reaches of the mighty Yellow River (Fig. 1). Situated in a semi-arid to subhumid climate, the rugged Loess Plateau region has the world largest loess-paleosol deposit with a soil depth of up to $100 \mathrm{~m}$ on an elevation ranging from 1200 to $1600 \mathrm{~m}$ a.s.l. Due to the long history of human settlement, natural vegetation cover is generally low, and land uses are predominantly cultivated croplands. The Loess Plateau is one of the most severely eroded areas in the world due to the loose loess soils, steep slopes, high rainfall intensity, and poor vegetation conditions (Li et al., 2009). The soil erosion and sedimentation issues have long been recognised as a security threat to the livelihoods of local communities in the Yellow River Basin. In 
order to control soil erosion and restore the ecological functions of watersheds, efforts have been made to plant trees and grasses on slope lands since the 1950s. A recent large reforestation campaign, the Grain-for-Green (GFG) project was implemented at the end of 1990 s, aiming at converting croplands and abandoned farmlands to forest and pasture lands (Xu and Cao, 2002).

The positive effects of the decade-long GFG project on regional vegetation cover recovery have been documented. For example, in northern Shaanxi Province, the combined planted forest and herbaceous vegetation (i.e., grasses, forbs and herbs) increased from $29.7 \%$ in 1998 to $42.2 \%$ in 2005 as a result of the GFG project (Cao et al., 2009). Also, recovery of natural vegetation and soil conservation practices have shown to be effective in controlling soil erosion ( $\mathrm{He}$ et al., 2003; Feng et al., 2010) as evidenced by the reduced sediment loading in many large rivers in the region. However, some concerns have been raised with argument that large-scale afforestation in the water-limited arid and semiarid regions may increase the severity of water shortages on the ground that plantation forests consume more water than grassland or degraded lands (Eastham and Rose, 1988; Sun et al., 2006; Zhang et al., 2008a; Wang et al., 2011). McVicar et al. (2007) conduct a comprehensive literature review on relations between land use and hydrology for the Loess Plateau region. The results overwhelmingly confirm that annual streamflow is reduced by forestation in this arid region. Water yield reduction for the cases examined varied from $10 \%$ to $70 \%$. Bi et al. (2009) reports that forestation reduced annual streamflow by $49.6 \%$ (or $6.5 \mathrm{~mm}$ per year). Zhang et al. (2008a, b)'s time series analysis for multiple large basins across the regions suggests that soil conservation practices that include both tree planting and engineering methods (check dams, terracing) partially explained the observed streamflow declines. A recent north-China wide comparison studies on forest cover's role in regulating streamflow by Wang et al. (2011) concludes that forest cover percentage has a clear negative relationship with streamflow rate, reconfirming previous watershed studies in the region. Those findings are consistent with world-wide forest hydrology literature that suggests reforestation practices on grasslands generally reduces water yield at the small watershed scale (Bush and Hewlett, 1982; Andreassian, 2004; Brown et al., 2005).

For specific watersheds, however, to detect the effects of vegetation restoration or land use change on flow can be challenging in this dry region that is dominated by a few large stormflow events annually. Wang et al. (2009) found that the average annual runoff coefficient over 1989-2003, a period of improved land cover, did not change significantly as compared to that in the period 1982-1988 (pre-vegetation restoration) in a small watershed located in a western part of the Loess Plateau. However, they concluded that water yield reduction caused by vegetation restoration was detectable in high precipitation years. It appears that the extent of the hydrologic response to land cover change varied greatly for study areas located in different climatic regimes over time. Few studies have been conducted to examine the relationship between vegetation change and hydrological response at a regional scale for the Loess Plateau. Indeed, small watershed experiment studies worldwide (Zhang et al., 2001; Andreassian, 2004) and continental scale modelling studies suggest the hydrologic influences of vegetation restoration vary across a climatic gradient (Ma et al., 2008) and over the course of plant community establishment (Sun et al., 2006). However, few case studies (Sun et al., 2006, 2011b) are available to extend small-watershed study results to a large basin or a region although land management planning and policy decisions are made at those scales (Wei et al., 2011).

Regional annual water yield of the Loess Plateau area, like any terrestrial ecosystems, is controlled mostly by precipitation and evapotranspiration (ET) (Budyko, 1974; Potter et al., 2005). Changes in land use/land cover and climate can directly impact the regional hydrological cycle by altering ET processes (Zhang et al., 2001, 2004; Sun et al., 2011a). Previous studies on the vegetation-water yield relationships for the Loess Plateau region focus on annual ET modelling using Zhang's ET model (McVicar et al., 2007; Ma et al., 2008; Zhang et al., 2008a, b). The existing "curve-type" ET models (Zhang et al., 2001) that are generally believed to be easy to use for continental scale studies or sensitivity analysis, but they remain difficult to apply for regional scale water balance calculations because they do not explicitly account for vegetation characteristics and the seasonal dynamics of key controls on actual ET. For example, Zhang (2001)'s ET model considers two major land cover, forest and grass, represented by an empirical parameter $w$. However, when the model is applied at the regional scale, it is difficult to determine its numerical values for heterogeneous watersheds that are affected by land cover, soil, geology and topography (Zhang et al., 2008a, b). In addition, large basins generally have complex landcover compositions beyond forest and grass lands.

Consequently, practical models are not readily available to quantify the regional hydrological effects of vegetation restoration on the Loess Plateau, and it remains challenging to extrapolate small watershed study results to the regional scale. To our knowledge, no attempts have been made to quantify the land cover change and climate variability on regional water yield for the Loess Plateau as a whole, largely due to the lack of reliable and practical hydrological models. The commonly-used process based hydrological model such as SWAT (Li et al., 2009) was not feasible because hydrological responses to vegetation restoration vary across the Loess Plateau, a region that has a strong north-south gradient in precipitation and terrain.

The objectives of this study included: (1) developing and validating a monthly ET model for estimating regional annual water yield; and (2) applying the ET model to examine the effects of a large vegetation restoration programme (GFG) on water yield for the entire Loess Plateau region during 1999-2007. 

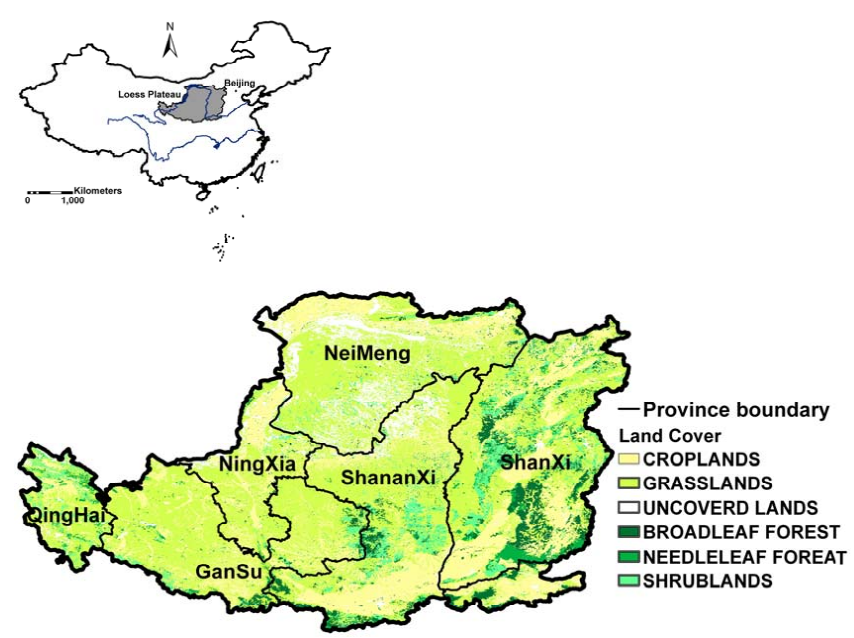

Fig. 1. Location and land cover of the Loess Plateau.

\section{Method and materials}

\subsection{The study region}

This study covers the entire Loess Plateau region that includes seven administrative Provinces in northwestern China. The region is controlled by a monsoon climate with an annual precipitation varying from $200 \mathrm{~mm}$ in the northwest to about $750 \mathrm{~mm}$ in the southeast (Fig. 2). Most precipitation occurs in the rainy season from June to September in the form of high intensity rainstorms. The northwest-southeast precipitation gradient strongly influences the vegetation distribution patterns (Fig. 1) that are dominated by forests in the south and grasslands in the north. The mean air temperature is about $0-13{ }^{\circ} \mathrm{C}$, and a warming trend in recent decades has been reported (Li et al., 2008; Wang, 2008).

\subsection{Monthly ET and annual water yield $(Q)$ estimates}

We estimate annual water yield at the 1-km spatial scale as the difference between annual precipitation (PPT) and annual total water loss, i.e., the sum of monthly ET:

$Q=\mathrm{PPT}-\mathrm{ET} \pm \Delta S$

When estimating annual water yield or annual ET by this equation, we assume that the change in soil water storage $(\Delta S)$ is negligible for normal years, but may cause large errors in extreme climatic conditions (Donohue et al., 2007). Fortunately, the streamflow of Loess Plateau region is dominated by surface runoff, and annual changes of soil water and groundwater are not likely to be large in order to cause a concern for annual estimate of ET by the water balance method. The watershed water balance approach is a common practice and reliable method in estimating ET at watershed scale when streamflow and precipitation are available (Palmroth et al., 2010).

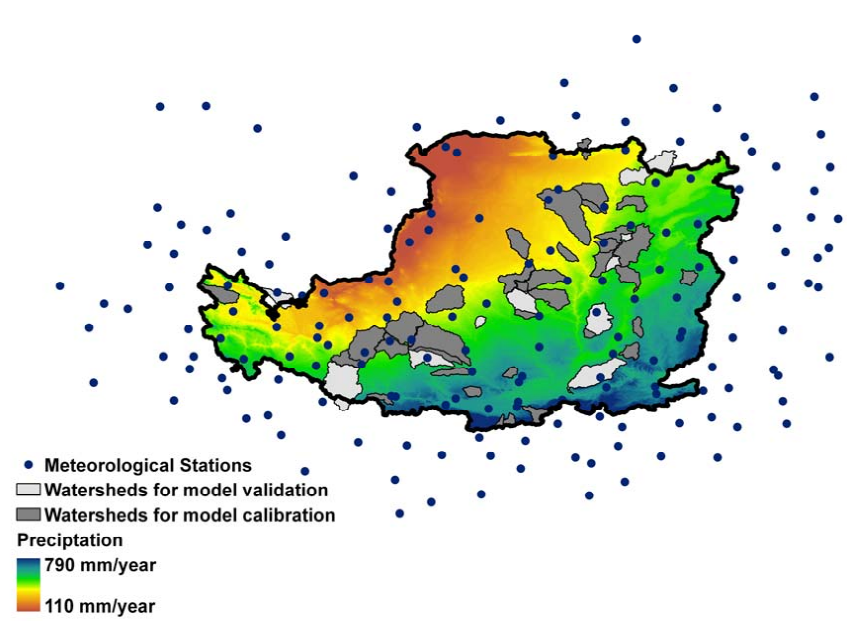

Fig. 2. Spatial distributions of gauged watersheds and meteorological stations used for model development and application.

Monthly ET is estimated by a monthly scale ET model as described below. Monthly actual ET can be sufficiently predicted by potential ET (PET), precipitation, and leaf area index (Sun et al., 2011a). This study adopted the same logic to develop an ET model by employing a subset of the eddy flux ET database for dry regions. Predicted ET was validated at two scales, watershed annual ET derived from gauged watersheds and regional monthly and annual ET estimates derived from MODIS remote-sensing products.

As described in Sun et al. (2011a), monthly ET can be estimated from key environmental controls that include available energy (i.e., potential evapotranspiration, PET), water (i.e., precipitation, PPT) and seasonal vegetation biomass dynamics (i.e., Leaf Area Index). Thus, the ET model has the following form:

$\mathrm{ET}=f(\mathrm{PET}, \mathrm{PPT}, \mathrm{LAI})$

We used a subset of the ET flux databases in Sun et al. (2011a) for model development that only include ecosystems of dry forests and grasslands in China, Australia and the US, a total of 10 sites. The 10 sites cover non-humid regimes as indicated by average air temperature $\left(0.6-17^{\circ} \mathrm{C}\right)$ and annual precipitation $\left(148-840 \mathrm{~mm} \mathrm{yr}^{-1}\right)$, resulting in a large difference in vegetation conditions (i.e., leaf area index, LAI) and water balance patterns. For example, low annual precipitation and PET supported low LAI plant communities in the Kubuqi shrub and poplar plantation sites in a desert environment of Inner Mongolia in western China. On the Paringa site on the Liverpool Plain in eastern Australia, a combination of high PET and uneven distribution of rainfall helped explain the periodic water stress experienced by this waterlimited ecosystem. The observation period varied from one full growing season to three years. This database contains 134 records (i.e., 134 site-months). Detailed descriptions of the study sites can be found in Sun et al. (2011a). 
In this study we used a simpler Hamon PET method (Hamon, 1963) as described below to replace the PET method used in Sun et al. (2011a) to reduce climatic input data needed for regional analysis. Spatial distribution of monthly PET was mapped at the $1 \mathrm{~km}$ scale as a function of air temperature and day length.

$$
\begin{aligned}
& \mathrm{PET}=0.1651 \cdot \mathrm{Ld} \cdot \mathrm{RHOSAT} \cdot \mathrm{Nd} \\
& \mathrm{Ld}=\operatorname{arcos}(-\tan \psi \tan \delta) \\
& \delta=0.4093 \cdot \sin ((2 \pi / 365) \cdot J-1.405) \\
& \mathrm{RHOSAT}=216.7 \cdot \mathrm{ESAT} /(T+273.3) \\
& \mathrm{ESAT}=6.108 \cdot \mathrm{EXP}(17.26939 \cdot T /(T+237.3))
\end{aligned}
$$

where, $\mathrm{Ld}$ is the average daytime length of each month, RHOSAT is the saturated vapour density $\left(\mathrm{g} \mathrm{m}^{-3}\right)$ at monthly mean air temperature $\left(T,{ }^{\circ} \mathrm{C}\right)$; ESAT is the saturated vapour pressure (mb) at the given $T$; and $\mathrm{Nd}$ is the day number of each month. $\psi$ is the latitude, $\delta$ is the solar declination (in radians) and $J$ is the Julian day. When calculating monthly PET from monthly climate data, the middle date of each month was used to represent the mean Julian date.

Regression models that relate ET, PET, PPT and LAI for the entire dataset were developed using the SAS regression procedure (SAS 9.2, 2010). Different combinations of the independent variables (PPT, LAI and PET) were tested to derive the best fit of observed data. Influences of PET, PPT and LAI on ET for each site were determined by Pearson correlation coefficients with a significance level of 0.01 . When pooling all the data of 134 point-scale measurements from the ten ET flux sites, we found that $61 \%, 3.5 \%$ and $17 \%$ of monthly ET variability was explained by the terms PET - PPT, PPT - LAI and PET - LAI, respectively. All variables in the above equation were highly significant $(P<$ 0.0001). The monthly ET for semi-arid and arid region, thus, has the following form:

$$
\mathrm{ET}=k 1+k 2 \cdot \mathrm{PET} \cdot \mathrm{PPT}+k 3 \cdot \mathrm{PPT} \cdot \mathrm{LAI}+k 4 \cdot \mathrm{PET} \cdot \mathrm{LAI}
$$

This model clearly shows that precipitation and PET are two major drivers for ET in the study regions. To further constrain the values of the parameters $k 1, k 2, k 3$ and $k 4$ for the Loess Plateau region, we need the local data to calibrate the model. The calibration was conducted through parameter research to acquire the best fit between local measured and estimated ET values with the SAS 9.2 software. The performance of the model was evaluated qualitatively using scatter plots and difference maps, Coefficients of Determination $\left(R^{2}\right)$ and the slopes of the linear regression models.

\subsection{Regional database for ET model calibration, validation and application to estimate water yield}

The ET model developed in this study was calibrated and validated with watershed scale annual ET estimates that were derived based on the watershed-balance method (i.e., PPT-Q method). We acquired monthly streamflow data (Table 1 ) for 48 randomly distributed catchments monitored by the Yellow River Conservancy Commission. The catchments cover a wide range of climatic and hydrologic conditions with a size ranging from 215 to $8704 \mathrm{~km}^{2}$. This method (referred to as Water-Balance-ET hereafter) represents the most feasible approach for obtaining meso-scale ET across the Loess Plateau and offers an independent dataset for validating other regional ET products (i.e., MODIS-ET) or modelled ET at a large scale. Simulated annual ET was calculated as the sum of monthly ET scaled to the watershed scale using the ESRI ARCGIS spatial analysis tools.

To examine ET model performance at a regional scale, simulated ET for high precipitation year (2003), average precipitation year (2006) and relatively low precipitation year (2005) by the monthly ET model was compared to a remote-sensing product by Mu et al. (2007). MODIS-ET was developed using the Penman-Monteith logic and MODIS imagery, and global meteorological data. The MODIS-ET algorithm employs reanalysed surface meteorological data $\left(0.05^{\circ}\right.$ resolution) from the NASA Global Modelling and Assimilation Office with MODIS land cover, albedo, LAI and the Fraction of Absorbed Photosynthetically Active Radiation (FPAR) inputs for regional and global ET mapping and monitoring with $1 \mathrm{~km}$ resolution. The global ET model has been successfully evaluated using various flux datasets (Mu et al., 2007; Sun et al., 2011b). Monthly LAI dynamic data are needed to drive the monthly ET model. LAI was estimated by an empirical relationship between LAI and remotely sensed NDVI (normalised difference vegetation index) derived locally for the study region (Hu, 2006). NDVI data were compiled from different sources because of the limitation of data availability for different time periods. GIMMS AVHRRNDVI data were used to describe vegetation conditions in the period 1980-1999, while SPOT VEGETATION data was used in the period 1999-2007. The two datasets were applied on different stages of model work. GIMMS AVHRR-NDVI was important model inputs for the calibration and validation. It was approved to be well-suited for vegetation studies of arid and semi-arid areas (Fensholt et al., 2009), which makes it helpful in building regional ET model. SPOT VEGETATION NDVI was used in model application before and after GFG project. It was considered an improvement over AVHRR GIMMS especially in spatial resolution (Fensholt et al., 2009). The uncertainty caused by using different vegetation sensors was reduced by the following trend analysis of model application.

Monthly climate data (precipitation and temperature) for the time period of 1980-2007 were acquired from 172 stations within and near the Loess Plateau region (State $\mathrm{Bu}-$ reau of Meteorology, $2011 \mathrm{http}: / /$ cdc.cma.gov.cn/home.do) (Fig. 2). The 1-km resolution DEM from the US Geological Survey global HYDRO1K product was used to derive gridded climate data. Combining climatologic and topographic data, the point climate data were interpolated at a $1 \mathrm{~km}$ 
Table 1. Hydrometeorolgical characteristics of catchments for model calibration and validation.

\begin{tabular}{|c|c|c|c|c|c|c|}
\hline $\begin{array}{l}\text { Hydrological } \\
\text { Station }\end{array}$ & Station Location & $\begin{array}{r}\text { Catchment Area } \\
\left(\mathrm{km}^{2}\right)\end{array}$ & $\begin{array}{l}\text { Mean Annual Runoff } \\
\qquad\left(\mathrm{m}^{3} \mathrm{~s}^{-1}\right)\end{array}$ & $\begin{array}{l}\text { Annual Precipitation } \\
\qquad(\mathrm{mm})\end{array}$ & Data Period & $\begin{array}{c}\text { For Calibration }(\mathrm{C}) \\
\text { or Validation }(\mathrm{V})\end{array}$ \\
\hline BeiXia & $35^{\circ} 34^{\prime} \mathrm{N} ; 105^{\circ} 45^{\prime} \mathrm{E}$ & 2726 & 545.0 & 434 & 1981-1986 & $\mathrm{C}$ \\
\hline BiCun & $38^{\circ} 31^{\prime} \mathrm{N} ; 110^{\circ} 53^{\prime} \mathrm{E}$ & 1423 & 323.5 & 496 & $1981-1985$ & $\mathrm{C}$ \\
\hline ChanKou & $35^{\circ} 41^{\prime} \mathrm{N} ; 104^{\circ} 33^{\prime} \mathrm{E}$ & 1709 & 255.1 & 456 & 1981-1987 & $\mathrm{C}$ \\
\hline DaNaoBao & $40^{\circ} 37^{\prime} \mathrm{N} ; 110^{\circ} 43^{\prime} \mathrm{E}$ & 931 & 333.0 & 350 & 1981-1986, 1988 & $\mathrm{C}$ \\
\hline DaNing & $36^{\circ} 28^{\prime} \mathrm{N} ; 110^{\circ} 43^{\prime} \mathrm{E}$ & 3796 & 1120.99 & 536 & $1981-1989$ & $\mathrm{~V}$ \\
\hline DangYangQiao & $39^{\circ} 59^{\prime} \mathrm{N} ; 111^{\circ} 37^{\prime} \mathrm{E}$ & 5025 & 1151.40 & 404 & $1981-1989$ & $\mathrm{~V}$ \\
\hline DongZhuang & $36^{\circ} 13^{\prime} \mathrm{N} ; 111^{\circ} 52^{\prime} \mathrm{E}$ & 952 & 514.29 & 557 & $1981,1982,1984$ & $\mathrm{C}$ \\
\hline DuDui & $37^{\circ} 43^{\prime} \mathrm{N} ; 113^{\circ} 11^{\prime} \mathrm{E}$ & 1161 & 425.53 & 559 & $1981-1987$ & $\mathrm{C}$ \\
\hline FenHe Reservoir & $38^{\circ} 03^{\prime} \mathrm{N} ; 111^{\circ} 56^{\prime} \mathrm{E}$ & 5224 & 2603.51 & 495 & 1981-1987 & $\mathrm{C}$ \\
\hline GeDong & $37^{\circ} 53^{\prime} \mathrm{N} ; 111^{\circ} 14^{\prime} \mathrm{E}$ & 838 & 435.03 & 501 & 1981-1989 & $\mathrm{V}$ \\
\hline GuYuan & $36^{\circ} 01^{\prime} \mathrm{N} ; 106^{\circ} 18^{\prime} \mathrm{E}$ & 215 & 87.05 & 461 & $1981-1985,1988$ & $\mathrm{C}$ \\
\hline GuoChengYi & $36^{\circ} 13^{\prime} \mathrm{N} ; 104^{\circ} 53^{\prime} \mathrm{E}$ & 5404 & 614 & 390 & $1981-1987$ & $\mathrm{C}$ \\
\hline HanFuWan & $36^{\circ} 36^{\prime} \mathrm{N} ; 106^{\circ} 09^{\prime} \mathrm{E}$ & 5045 & 538.0 & 391 & 1981-1986, 1988 & $\mathrm{C}$ \\
\hline HanJiaMao & $38^{\circ} 04^{\prime} \mathrm{N} ; 109^{\circ} 09^{\prime} \mathrm{E}$ & 2518 & 1004.38 & 329 & $1981-1989$ & $\mathrm{C}$ \\
\hline HaoSiHe & $34^{\circ} 36^{\prime} \mathrm{N} ; 108^{\circ} 03^{\prime} \mathrm{E}$ & 961 & 1049.35 & 642 & $1981-1983,1985,1986$ & $\mathrm{C}$ \\
\hline HengShan & $37^{\circ} 58^{\prime} \mathrm{N} ; 109^{\circ} 17^{\prime} \mathrm{E}$ & 2689 & 678.06 & 394 & $1981-1989$ & $\mathrm{C}$ \\
\hline HongDe & $36^{\circ} 46^{\prime} \mathrm{N} ; 107^{\circ} 12^{\prime} \mathrm{E}$ & 4580 & 616.92 & 369 & $1981-1987$ & $\mathrm{C}$ \\
\hline HuangFu & $39^{\circ} 17^{\prime} \mathrm{N} ; 111^{\circ} 05^{\prime} \mathrm{E}$ & 3249 & 1320.91 & 384 & 1981-1989 & $\mathrm{C}$ \\
\hline HuiHe Reservoir & $35^{\circ} 39^{\prime} \mathrm{N} ; 111^{\circ} 34^{\prime} \mathrm{E}$ & 1328 & 575.97 & 585 & 1983-1987 & $\mathrm{C}$ \\
\hline JiXian & $36^{\circ} 05^{\prime} \mathrm{N} ; 110^{\circ} 40^{\prime} \mathrm{E}$ & 455 & 115.37 & 549 & 1981-1989 & $\mathrm{C}$ \\
\hline JingChuan & $35^{\circ} 20^{\prime} \mathrm{N} ; 107^{\circ} 21^{\prime} \mathrm{E}$ & 3150 & 2194.84 & 533 & 1981-1987 & $\mathrm{V}$ \\
\hline KeLan & $38^{\circ} 42^{\prime} \mathrm{N} ; 111^{\circ} 34^{\prime} \mathrm{E}$ & 402 & 137.75 & 513 & 1981-1989 & V \\
\hline LaoYuKou & $34^{\circ} 01^{\prime} \mathrm{N} ; 108^{\circ} 32^{\prime} \mathrm{E}$ & 398 & 1789.58 & 869 & $1981-1984,1986$ & $\mathrm{C}$ \\
\hline LinJiaCun & $34^{\circ} 23^{\prime} \mathrm{N} ; 107^{\circ} 03^{\prime} \mathrm{E}$ & 633 & 3503.95 & 811 & $1981-1986$ & $\mathrm{C}$ \\
\hline LinJiaPing & $37^{\circ} 42^{\prime} \mathrm{N} ; 110^{\circ} 52^{\prime} \mathrm{E}$ & 1969 & 553.63 & 462 & 1981-1989 & $\mathrm{C}$ \\
\hline LiuLin & $35^{\circ} 03^{\prime} \mathrm{N} ; 108^{\circ} 49^{\prime} \mathrm{E}$ & 672 & 1032.80 & 620 & 1981-1986 & $\mathrm{C}$ \\
\hline LvZhuang Reservoir & $35^{\circ} 23^{\prime} \mathrm{N} ; 111^{\circ} 15^{\prime} \mathrm{E}$ & 823 & 519.9 & 577 & $1983-1985$ & $\mathrm{C}$ \\
\hline MaDuWang & $34^{\circ} 14^{\prime} \mathrm{N} ; 109^{\circ} 09^{\prime} \mathrm{E}$ & 1645 & 7884.38 & 732 & 1981-1986 & $\mathrm{C}$ \\
\hline MaoJiaHe & $35^{\circ} 31^{\prime} \mathrm{N} ; 107^{\circ} 35^{\prime} \mathrm{E}$ & 7381 & 1985.58 & 466 & 1981-1987 & $\mathrm{C}$ \\
\hline PeiJiaChuan & $38^{\circ} 37^{\prime} \mathrm{N} ; 110^{\circ} 54^{\prime} \mathrm{E}$ & 2080 & 376.14 & 488 & 1981-1985 & $\mathrm{C}$ \\
\hline PianGuan & $39^{\circ} 28^{\prime} \mathrm{N} ; 111^{\circ} 30^{\prime} \mathrm{E}$ & 1879 & 215.93 & 444 & $1981-1989$ & $\mathrm{C}$ \\
\hline QiaoTou & $36^{\circ} 56^{\prime} \mathrm{N} ; 101^{\circ} 41^{\prime} \mathrm{E}$ & 2745 & 430.23 & 493 & 1981, 1982, 1984, 1986 & $\mathrm{C}$ \\
\hline QingYangCha & $37^{\circ} 22^{\prime} \mathrm{N} ; 109^{\circ} 13^{\prime} \mathrm{E}$ & 636 & 282.02 & 420 & $1981-1989$ & $\mathrm{C}$ \\
\hline QingShui & $39^{\circ} 15^{\prime} \mathrm{N} ; 111^{\circ} 03^{\prime} \mathrm{E}$ & 747 & 340.39 & 397 & 1981-1989 & $\mathrm{C}$ \\
\hline ShenJiaWan & $38^{\circ} 02^{\prime} \mathrm{N} ; 110^{\circ} 29^{\prime} \mathrm{E}$ & 1110 & 459.68 & 400 & 1981-1989 & $\mathrm{C}$ \\
\hline SuiDe & $37^{\circ} 30^{\prime} \mathrm{N} ; 110^{\circ} 14^{\prime} \mathrm{E}$ & 3850 & 1478.39 & 415 & $1981-1989$ & $\mathrm{C}$ \\
\hline TianShui & $34^{\circ} 35^{\prime} \mathrm{N} ; 105^{\circ} 41^{\prime} \mathrm{E}$ & 979 & 1029.23 & 577 & $1981-1984,1986$ & $\mathrm{C}$ \\
\hline WenJiaChuan & $38^{\circ} 26^{\prime} \mathrm{N} ; 110^{\circ} 45^{\prime} \mathrm{E}$ & 8704 & 6141.61 & 378 & $1981-1989$ & $\mathrm{C}$ \\
\hline WenYuHe Reservoir & $37^{\circ} 30^{\prime} \mathrm{N} ; 112^{\circ} 01^{\prime} \mathrm{E}$ & 2120 & 1224.06 & 509 & $1981-1987$ & $\mathrm{C}$ \\
\hline WuShan & $34^{\circ} 44^{\prime} \mathrm{N} ; 104^{\circ} 53^{\prime} \mathrm{E}$ & 8251 & 8417.76 & 575 & $1981-1986$ & $\mathrm{~V}$ \\
\hline WuShengYi & $36^{\circ} 52^{\prime} \mathrm{N} ; 103^{\circ} 11^{\prime} \mathrm{E}$ & 1976 & 356.45 & 421 & 1981-1982, 1984, 1986, 1988 & $\mathrm{~V}$ \\
\hline Yan'an & $36^{\circ} 38 / \mathrm{N} ; 109^{\circ} 27 \mathrm{E}$ & 3125 & 1451.36 & 465 & $1981-1989$ & $\mathrm{~V}$ \\
\hline YanChuan & $36^{\circ} 53^{\prime} \mathrm{N} ; 110^{\circ} 11^{\prime} \mathrm{E}$ & 3359 & 1354.72 & 463 & 1981-1983, 1985-1989 & $\mathrm{C}$ \\
\hline YangLv & $35^{\circ} 26^{\prime} \mathrm{N} ; 107^{\circ} 30^{\prime} \mathrm{E}$ & 1342 & 509.78 & 500 & $1981-1987$ & $\mathrm{C}$ \\
\hline YueLe & $36^{\circ} 18 / \mathrm{N} ; 107^{\circ} 54 / \mathrm{E}$ & 585 & 158.89 & 464 & 1981-1987 & V \\
\hline ZaoYuan & $36^{\circ} 38^{\prime} \mathrm{N} ; 109^{\circ} 20^{\prime} \mathrm{E}$ & 774 & 325.71 & 501 & 1981-1989 & $\mathrm{C}$ \\
\hline ZhangHe & $35^{\circ} 11^{\prime} \mathrm{N} ; 107^{\circ} 43^{\prime} \mathrm{E}$ & 1387 & 813.29 & 559 & $1981-1987$ & $\mathrm{C}$ \\
\hline ZhangLiuZhuang & $34^{\circ} 50^{\prime} \mathrm{N} ; 110^{\circ} 19^{\prime} \mathrm{E}$ & 5738 & 402.30 & 573 & 1981-1987 & V \\
\hline
\end{tabular}

Table 2. Relationship between NDVI and LAI after Zhang et al., (2008c).

\begin{tabular}{lll}
\hline & Land cover & Equation \\
\hline 1 & Agriculture & $\mathrm{LAI}=0.7271 \cdot \exp (3.0236 \cdot \mathrm{NDVI})$ \\
21 & Broadleaf forest & $\mathrm{LAI}=0.5628 \cdot(1+\mathrm{NDVI}) /(1-\mathrm{NDVI})+0.3817$ \\
22 & Needleleaf forest & $\mathrm{LAI}=3.482 \cdot \mathrm{NDVI}+0.4378$ \\
23 & Shrub & $\mathrm{LAI}=1.1273 \cdot(1+\mathrm{NDVI}) /(1-\mathrm{NDVI})-0.3468$ \\
3 & Pasture & $\mathrm{LAI}=0.8253 \cdot \exp (0.3309 \cdot(1+\mathrm{NDVI}) /(1-\mathrm{NDVI}))$ \\
4 & Others & 0 \\
\hline
\end{tabular}

resolution with the thin-plate smoothing spline method provided by the ANUSPLIN 3.1 programme, (Wahba and Wendelberger, 1980; Hutchinson, 1991). The climate data interpolation method provides accurate estimates of spatial climatic variables by including the linear covariates rather than a constant lapse rate to represent the elevation effect on atmospheric pressure and temperature (Hutchinson, 1991) and also the method is able to provide a direct estimation of interpolation error and efficient diagnosis of data errors (Hutchinson and Gessler, 1994). 


\subsection{Model applications to examine water yield response to land cover change and associated climate variability}

At the annual scale, water yield from unregulated watersheds is mainly controlled by the balance between precipitation input and evapotranspiration (ET) output fluxes. ET is affected by both land cover and climate change and, therefore, so is water yield. Taking water yield as the difference between PPT and ET, this study focused on the time period of 1999-2007 to evaluate the effect of land-use change and climate variability on water resource, the water part potentially providing ecosystem services (surface runoff and soil water). Year 1999 and 2000-2007 represent pre- and post-vegetation restoration periods. Related studies have suggested that plant growth (indicated by NDVI) of the Loess Plateau have been increasing despite insignificant climate change during 19992007, and the implementation of GFG project was the driving factor (Xin et al., 2008; Zhang et al., 2011). In the case of the GFG - driven land cover change, the individual influences of vegetation restoration and climate variability were separated by comparing the model outputs of two schemes: (1) to determine the hydrologic effects of land cover change, the water yield model was run with a fixed climate of 1999 when the GFG project was first initiated and land cover has changed gradually during 1999-2007; (2) to determine the combined effects of both the climate and land cover, the water yield was calculated by changing the fixed climate to the observed annual precipitation and temperature. The difference between Table 2 and Table 1 gives the climatic effect on water yield given the observed changes in vegetation during the entire study period.

We used the MATLAB Programme to detect the trend of modelled annual water yield for each pixel by conducting linear regressions relating water resource with time (year). Regression coefficient was used to predict rate of annual water yield variations before and after GFG project.

$$
b=\frac{\sum_{i=1}^{9}\left(w_{i}-\bar{w}\right)\left(y_{i}-\bar{y}\right)}{\sum_{i=1}^{9}\left(w_{y_{i}}-\bar{w}\right)^{2}}
$$

where $i$ is the sequential year, $w_{i}$ is the annual water yield in the year $y_{i}, \bar{w}$ and $\bar{y}$ are the mean value.

A positive or negative value predicts the increase or decrease rate of annual water yield. If the regression coefficient passes through the significance test $(P<0.05)$, it shows an "significant" ascending or descending trend.

Paired sample T-test (two-tailed) was carried out with MATLAB Programme for each pixel to detect significant differences of annual the water yield for 1999-2007 between Table 1 and Table 2 . The level of significance was set as $P<0.05$.

\section{Results}

\subsection{ET model performance}

Water-Balance-ET dataset was split into subsets for calibration and validation (Table 1). Watersheds in both subsets were randomly distributed to cover different precipitation gradient. More watersheds were used for model calibration to ensure the statistical regression analysis. With the calibrated parameters, predicted ET compared well with Water-Balance-ET. The overall error of model prediction was $40 \mathrm{~mm}$ per year (about $3 \mathrm{~mm}$ per month). The predicted error was $9.7 \%$ of the ET value for the entire Loess Plateau region. The term PET - LAI contributed very little in the Loess Plateau region, and the term was dropped. We used the simplified model in the following application at the regional scale.

$\mathrm{ET}=9.78+0.0072 \cdot \mathrm{PET} \cdot \mathrm{PPT}+0.05142 \cdot \mathrm{PPT} \cdot \mathrm{LAI}$

For model validation at the watershed scale, the modelled annual ET datasets were derived from monthly simulation using Eq. (10). A fairly high regression coefficient $\left(R^{2}\right)$ of 0.87 and a slope of 0.97 were achieved when the intercept was set to zero. The model overestimated somewhat for the drier watersheds where ET was less than $400 \mathrm{~mm} \mathrm{yr}^{-1}$, suggesting some uncertainty of the ET model for the extreme dry areas where ET is likely controlled by precipitation only. Overall, a single monthly ET model performed well across the region for predicting annual ET (Fig. 3).

The pixel-based correlation coefficients of the two ET datasets (Modelled ET vs. MODIS-ET) were 0.66, 0.74, and 0.72 in 2003, 2005 and 2006, respectively, suggesting that the modelled ET is in agreement with the MODIS ET product in spatial variability. However, we believe that the MODISET appeared to have over-underestimated ET. Modelled ET by this study was much higher than MODIS-ET. Our regression models showed that ET accounted for $90 \%$ of precipitation (Fig. 4). Especially in 2006, modelled ET was much higher than precipitation because the temperature was relative high in this year. While MODIS ET was much lower, less than $75 \%$ of precipitation from local interpolated stations in the wet and average precipitation years and $85 \%$ in the dry years (Fig. 4a). Hydrologic literature generally suggest that watersheds in the Loess Plateau region produce streamflow less than 5-10\% of precipitation (thus, 90-95\% of as ET) (Zhang et al., 2008a; Wang et al., 2009; Wang et al., 2011), and the runoff coefficients are even lower for fully forested watersheds or the desert area in the northern part of the study region (Chen et al., 2010). So, our ET estimates were more in agreement with field observations at the annual scale (Fig. 4b). The MODIS product severely underestimated ET not only at the annual scale, but also at the monthly scale (Fig. 4b). Most of the annual underestimation by MODIS occurred in the growing season. Monthly MODIS-ET appeared to be too low when compared to monthly precipitation 


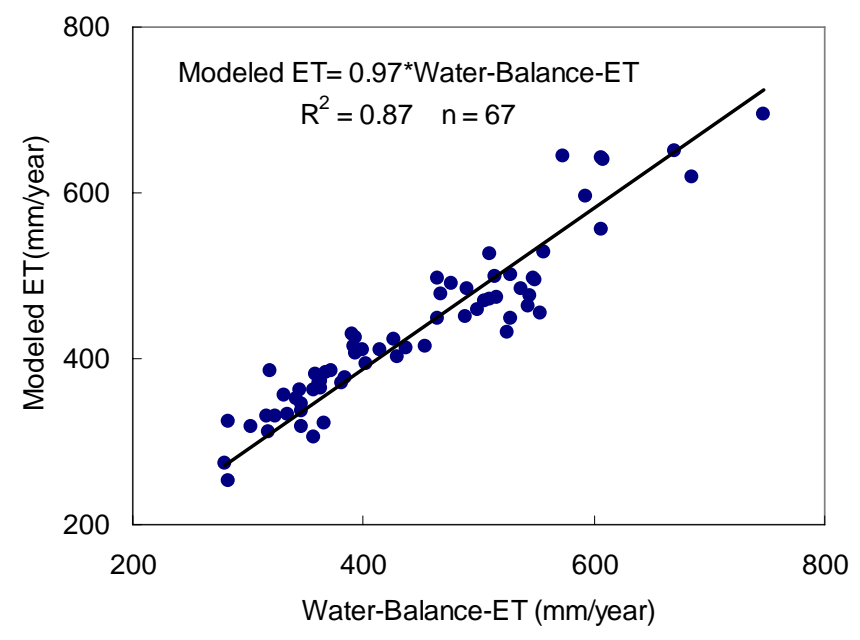

Fig. 3. ET Model validation using Water-Balance-ET data derived from hydrometeological data across the Loess Plateau region.

(ET $<50 \%$ of $P$ ) during the period of May to September. In general, monthly ET should equal or be slightly less than precipitation during the growing season for water-limited vegetated ecosystems (Sun et al., 2011a). Therefore, our model appeared to be superior to the MODIS-ET algorithms in performance for the study region when evaluated at the regional scale at two temporal scales.

\subsection{Spatial variability of annual water yield}

\subsubsection{Effects of land cover change only}

The results of trend analysis suggested that vegetation restoration only during the study period caused annual water yield to decrease as much as $1.6 \mathrm{~mm}$ per year on average across the Loess Plateau (Fig. 5a). Divided the trend in water yield over the period 1999-2007 by the baseline conditions in 1999, change in water yield can also be expressed in a relative term (Fig. 5b). About $26 \%$ of the study region located in the southeast portion (i.e., southern Shaanxi and Shanxi Provinces) had a significant decrease trend $(P<0.05$, T-test $)$ in water yield with a range of $1-48 \mathrm{~mm}$ per year, among which a small portion $(6 \%)$ experienced a decrease trend greater than $10 \mathrm{~mm}$ per year. About $19 \%$ of the study region located in the north portion (i.e., northern Shaanxi and Inner Mongolia Province) experienced less, but also a significant decrease ( $P<0.05, T$-test) (Figs. 5a, c and 6a). Because of the low baseline in these dry areas, the decrease less than $1 \mathrm{~mm}$ per year caused a relative value greater than $100 \%$ in water yield (Figs. $5 \mathrm{~b}$ and $6 \mathrm{~b}$ ).

\subsubsection{Effects of land cover change + climate variability}

The combined water yield responses to land cover change and climate variability during 1999-2007 decreased by $1.0 \mathrm{~mm}$ per year on the Loess Plateau as a whole. The signifi- cant difference in water yield trend between combined effect and land cover only occurred in northern Shaanxi, Shanxi and Inner Mongolia Province (Fig. 5g). Because of the climate effect, the significant water yield decrease in these areas had changed to an insignificant increase with a range of 1$10 \mathrm{~mm}$ per year (Fig. 5d). As expected, small changes in water yield amount resulted in a large relative change in the dry portion (northern Shaanxi, northwestern Shanxi and Inner Mongolia Province) due to their low background (Figs. 5e and $6 \mathrm{c}$ ). Because of the climate effect, about $37 \%$ of the study area saw a decrease in water yield within a range of $1-54 \mathrm{~mm}$ per year, among which only $4 \%$ of the study region (southern Shaanxi Province and southwestern Shanxi Province) has undergone a significant decrease $(P<0.05$, $T$-test) in water yield of more than $5 \mathrm{~mm}$ per year (Figs. $5 \mathrm{f}$ and 6a).

\subsection{Temporal variability of water yield}

Temporal water yield change for the entire Loess Plateau region was defined as the water yield amount in each year of the post-vegetation restoration period minus water yield under the baseline condition (i.e., in 1999). The water yield under the combined changes in land cover and climate followed closely with precipitation patterns during the period 1999-2007. Mean annual water yield across the region decreased during 2000-2007 except in 2000 and 2001 when a slight increase in water yield was noted (Fig. 7). We argue that the young forests or shrubs established by the project in the initial stage of early 2000s might not have caused an increase in ET and, thus, decrease in water yield. Both vegetation characteristics (i.e., LAI) and the size of the area of vegetation restored might not have significantly changed during 2000-2001. The restored ecosystems appeared to be stabilised three years after the implementation of the GFG project. The relative contribution of vegetation restoration to the total water yield reduction varied with precipitation. For example, we found a $10 \%$ of change in annual water yield in the wet years (i.e., 2003) and $56 \%$ of the annual change in dry years (i.e., year 2005).

\section{Discussion}

\subsection{Data and model uncertainty}

Several factors affect the accuracy of estimating annual water yield at the regional scale. First, the complex terrain of the Loess Plateau presents a challenge to derive the spatial distribution of annual precipitation that was interpolated from climate records at 172 weather stations. In addition, the seasonal and inter-annual variability of precipitation was considered to be high in the Loess Plateau region where summer storms were the major forms of precipitation. Thus, the large spatial and temporal variability of precipitation made it difficult to map accurately the distribution of precipitation at the 

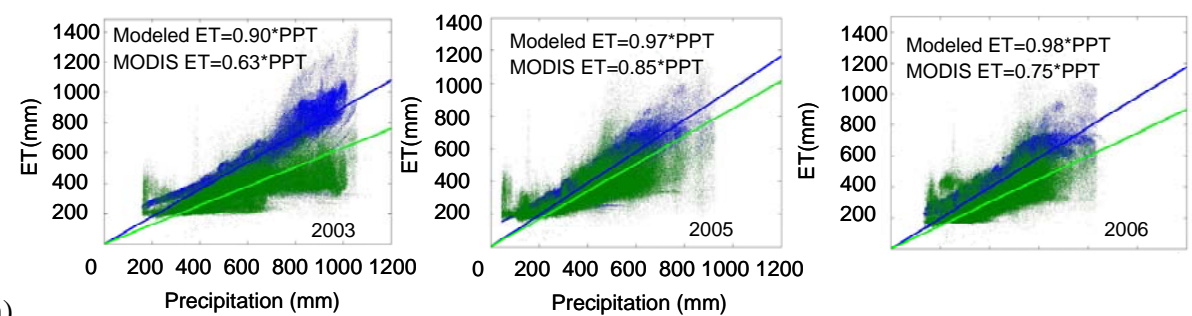

(a)
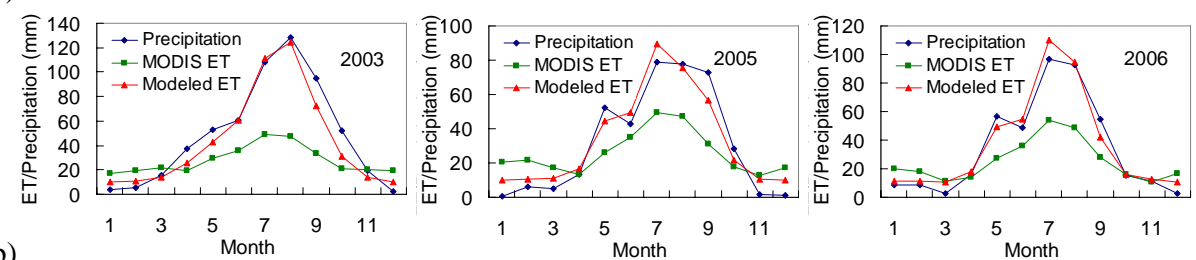

Fig. 4. (a) Pixel to pixel comparison between modelled ET and MODIS ET products in a dry year (2005), wet year (2003) and for average conditions (2006); (b) the monthly data comparison between modelled ET and MODIS ET products in a dry year (2005), wet year (2003) and for average conditions (2006).
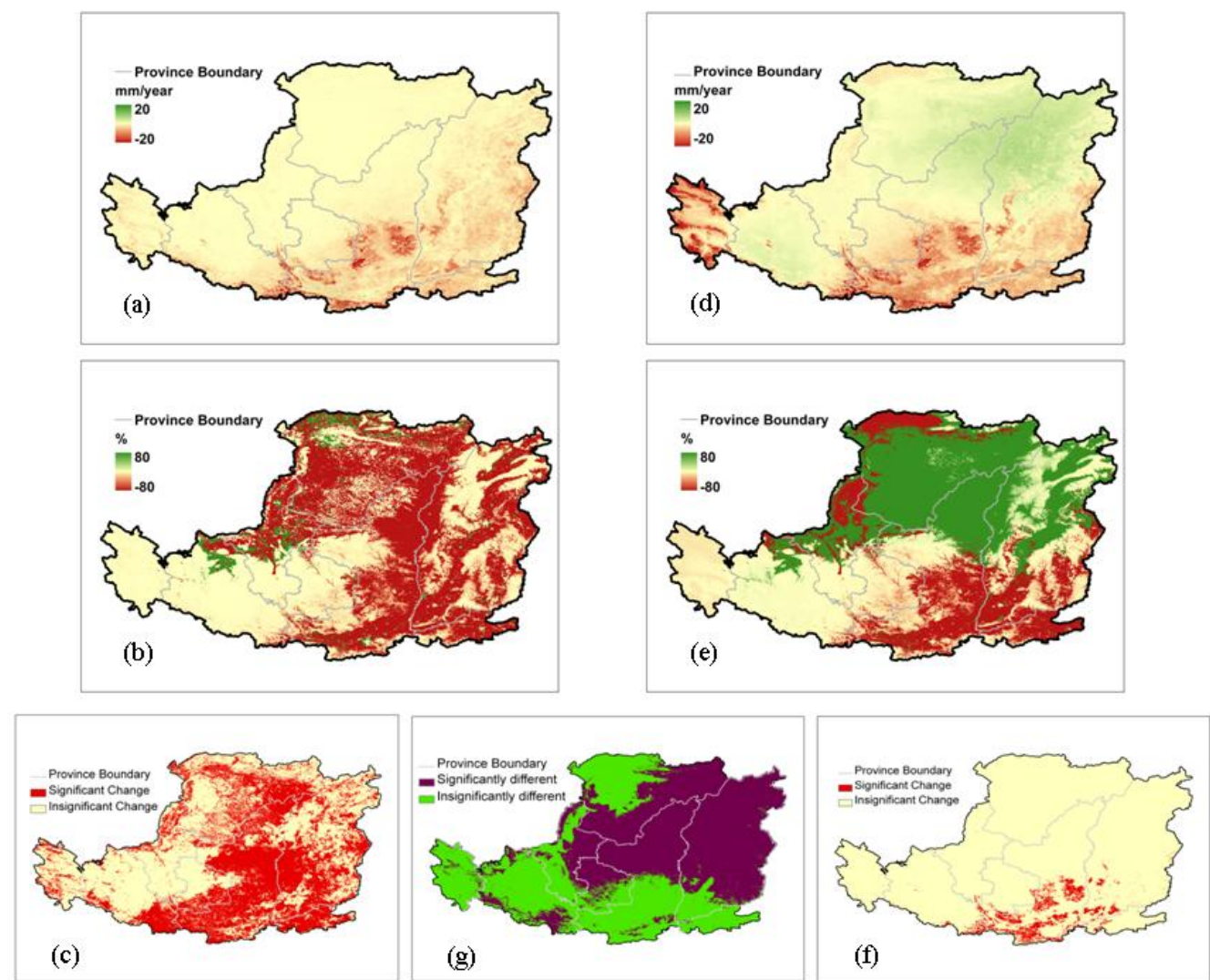

Fig. 5. (a) Spatial pattern of water yield change per year due to vegetation restoration; (b) its relative value; and (c) the significance of trend; (d) combined water yield change; (e) its relative value; and (f) the significance of trend in the period 2000-2007; and (g) the significance of the difference in water yield trend between combined change and land cover change only.

1-km scale, especially for remote areas that do not have sufficient converges of weather stations. In addition to precipitation, large uncertainty remains in ET estimates. Although our ET modelling results were believed to be much closer to reality than the remote-sensing based product (MODIS-ET), uncertainty remained for the seasonal distributions of ET by land cover type. The watershed-scale ET estimates derived from watershed water balances were used to calibrate and 


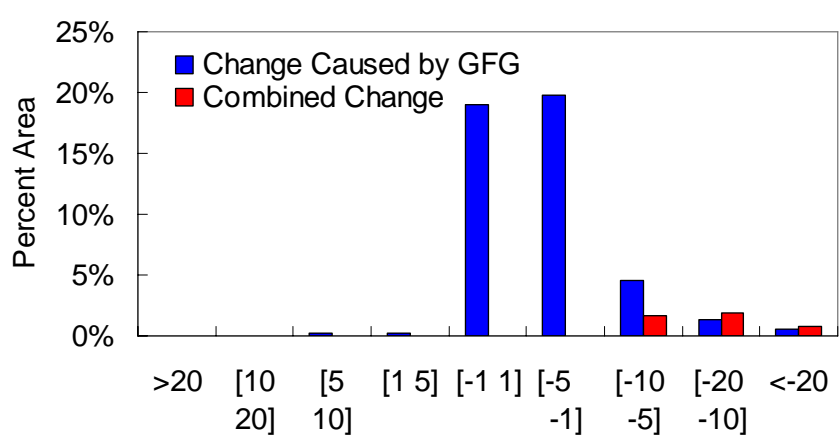

(a)

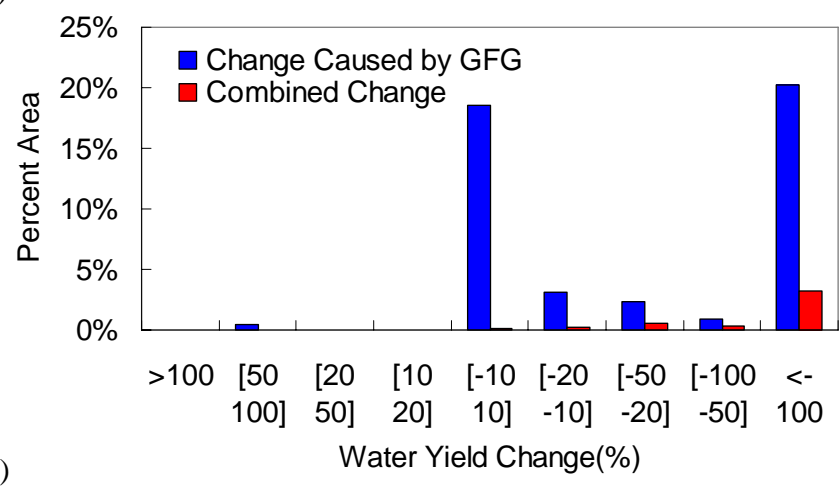

Fig. 6. (a) Frequency distribution of significant water yield change per year and (b) its relative value.

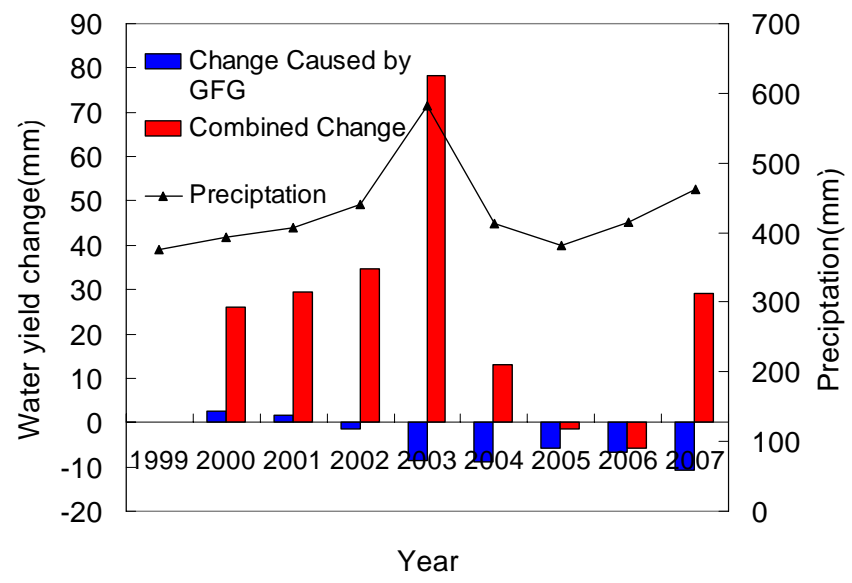

Fig. 7. Temporal variability of change in water yield due to land cover change only and combined climate and land cover change during 2000-2007.

validate the monthly ET model had uncertainty as well because of two reasons: (1) change in water storage may not be negligible for certain wet years; (2) human water withdrawal for irrigation use, especially soil conservation engineering (e.g., check dams) is in use, is not considered. In the study region, especially in the semi-arid areas in the northern part, small changes in ET would result in large error of water yield estimates. Although the water-balanced ET estimates are the most readily available hydrological data in the Loess Plateau, this method has a certain degree of uncertainty due to lacking of gauged watershed coverage.

\subsection{Spatial and temporal variability across a precipitation gradient}

This study clearly showed that spatial and temporal precipitation patterns influenced the hydrological effects of vegetation restoration, and climate variability explained most of the variability of water yield in the study region. Previous empirical and theoretical studies also conclude that the differences in water yield sensitivity to precipitation change increase dramatically when PET / $P$ ratio exceed 1.0 (i.e., dry regions) (Ma et al., 2008). Using a process based hydrological model (SWAT), Li et al. (2009) quantified the combined and individual influences of land use change and climate variability in the Heihe catchment located in our study region. Their studies concluded that land use change and climate variability reduced runoff by $9.6 \%$ and $95.8 \%$, respectively. In an empirical study on the Loess Plateau (Shiyang River), Ma et al. (2008) reported that climate variability and ecosystem restoration accounted for over $64 \%$ and $12-36 \%$ of the observed streamflow reduction, respectively. Our study showed the complexity of combined hydrologic responses at the regional scale: the magnitude of ET or water yield could be enhanced or cancelled by landcover and climate dynamics. We defined two types of combined response on ET: (1) ET increased (or water yield decreased) due to vegetation restoration in southern Shaanxi Province and the change was strengthened by climate variability both in areal extent and magnitude; and (2) the increase in ET or decrease in water yield due to vegetation restoration was masked by climate variability due to an increase in precipitation in northern Shanxi Province. Thus, vegetation recovery or restoration from degraded land did not automatically result in a decrease in water yield. The actual change was influenced by the spatial location of the land cover change and climatic conditions. Long-term climate trends and variability should be considered when planning regional vegetation restoration, especially in water-limited northwest Loess Plateau areas, so that the land cover and land use changes do not limit water availability beyond what can sustain human and ecosystem uses.

In the study region, effects of land cover change on water yield were most pronounced in the growing season. Plants almost exhausted the soil water supply through ET during the growing season in the Loess Plateau. Streamflow only occurred as flash stormflow during heavy storms (Wang et al., 2009). About $85 \%$ of the increase in ET or decrease in water yield was believed to occur during the growing season (May-September). At the annual scale, the land cover change caused a relatively higher impact on water yield in dry years. In general, our study results are consistent with findings in Yellow River Basin in northern China (Wang et al., 2011) and 
the forest hydrologic community on the hydrologic impacts of reforestation (Brown et al., 2005).

In contrast to deforestation studies, data on the hydrologic effects of vegetation recovery or forestation (i.e., reforestation and afforestion) on streamflow are scarce internationally (Andreassian, 2004). Thus, there are still uncertainties about the true effects of reforestation on the water yield and more studies are needed. Based on climate and physiographic conditions, a modelling study by Sun et al. (2006) proposed differential hydrologic recovery rates for five subregions that have different climate across China, and stressed the importance of timing and extent of reforestation activities on the potential hydrologic impacts. A recent study by Zhou et al. (2010) suggested that forest recovery in the humid southeast China in the past $50 \mathrm{yr}$ did not necessarily reduce streamflow, but rather helped redistributing water from the wet season to the dry season and, consequently, elevating water yield in the dry season. A recent regional study by Price et al. (2011) found that undisturbed forested watersheds in southeastern US with high precipitation had higher baseflow rates than areas with less forest covers in spite of the higher ET rates in forests. The authors attributed the higher baseflow in forests to higher infiltration rates. Those limited regional-scale studies challenge traditional "paired watershed" research results.

Due to the large spatial and temporal variability of climate and land uses across regional Loess Plateau, one single ET model may not fit all land cover types. Although our models can be used to assess the general trend, but accurately quantifying ET remain challenging since ET is rather component of the water balance in the arid region. Future studies in the Loess Plateau region should examine the effects of changes of vegetation restoration on infiltration, soil water dynamics and ET controls at a finer temporal scale and by land use types.

\section{Conclusions}

The effects of vegetation restoration on water yield are rarely evaluated at the regional scale. Due to the large spatial variability in climate and vegetation characteristics, findings on the vegetation-water yield relationship at a small watershed scale have not been readily applied to large areas on the Loess Plateau.

We built a monthly scale ET model by integrating eddy flux data, gauged watershed runoff measurements and remotely sensed vegetation parameters. Model validation suggested that our ET model developed specifically for the study region performs well and can be used for regional hydrologic analysis in the Loess Plateau region.

Our modelling study suggested that vegetation restoration caused a decrease of water yield on the Loess Plateau. The magnitude of water yield decrease varied spatially and temporally. Climate variability can mask or strengthen the wa- ter yield change caused by vegetation restoration alone, depending on the location of the vegetation restoration. Vegetation restoration has the highest relative impact in dry years, mostly occurring in the growing season because of the tight relationship between plant growth and water use.

We concluded that the effects ecological restoration was strongly influenced by climatic variability in the arid region. The current regional vegetation restoration projects have variable effects on local water resources across the region that has a large precipitation gradient. Future climate change in the study region is likely to alter the water balances due to both air warming and precipitation patterns. Land management planning must consider the influences of spatial climate variability and long-term climate change on water yield and other potential environmental impacts (Falloon and Betts, 2010; Wattenbach et al., 2007). Quantifying the hydrologic response at the regional scale is an essential step toward developing a sustainable ecological restoration programme in the Loess Plateau region.

Acknowledgements. The research was supported by National Basic Research Priorities Programme of China (No. 2009CB421104), National Natural Science Foundation of China (No. 40801070), the CAS/SAFEA International Partnership Programme for Innovation Research Teams of "Ecosystem Processes and Services". GIMMS AVHRR-NDVI data and SPOT VEGETATION data were provided from Environmental and Ecological Science Data Center for West China, (http://westdc.westgis.ac.cn). Partial support also comes from the USDA Forest Service Eastern Forest Environmental Threat Assessment Center. Also we would like to thank two anonymous reviewers for their comments and suggestions that helped improve the quality of this paper.

Edited by: J. Liu

\section{References}

Andreassian, V.: Waters and forests: from historical controversy to scientific debate, J. Hydrol., 291, 1-27, 2004.

Bi, H. X., Liu, B., Wu, J., Yun, L., Chen, Z. H., and Cui, Z. W.: Effects of precipitation and landuse on runoff during the past 50 years in a typical watershed in the Loess Plateau, China, Int. J. Sediment Res., 24, 352-364, 2009.

Brown, A. E., Zhang, L., McMahon, T. A., Western, A. W., and Vertessy, R. A.: A review of paired catchment studies for determining changes in water yield resulting from alterations in vegetation, J. Hydrol., 310, 28-61, 2005.

Budyko, M. I.: Climate and Life, translate from Russian by D. H. Miller, Academic, San Diego, Calif., 1974.

Cao, S. X., Chen, L., and Yu, X. X.: Impact of China's Grain for Green Project on the landscape of vulnerable arid and semi-arid agricultural regions: a case study in northern Shaanxi Province, J. Appl. Ecol., 46, 536-543, 2009.

Chen, L. D., Wang, J. P., Wei, W., Fu, B. J., and Wu, D. P.: Effects of landscape restoration on soil water storage and water use in the 
Loess Plateau Region, China, Forest Ecol. Manag., 259, 12911298, 2010.

Donohue, R. J., Roderick, M. L., and McVicar, T. R.: On the importance of including vegetation dynamics in Budyko's hydrological model, Hydrol. Earth Syst. Sci., 11, 983-995, doi:10.5194/hess11-983-2007, 2007.

Eastham, J. and Rose, C. W.: Pasture Evapotranspiration Under Varying Tree Planting Density in an Agroforestry Experiment, Agr. Water Manage., 15, 87-105, 1988.

Falloon, P. and Betts, R.: Climate impacts on european agriculture and water management in the context of adaptation and mitigation-the importance of an integrated approach, Sci. Total Environ., 408, 5667-5687, 2010.

Feng, X. M., Wang, Y. F., Chen, L. D., Fu, B. J., and Bai, G.: Modeling soil erosion and its response to land-use change in hilly catchments of the Chinese Loess Plateau, Geomorphology, 118, 239-248, 2010.

Fensholt, R., Rasmussen, K., Nielsen, T. T., and Mbow, C.: Evaluation of earth observation based long term vegetation trends - Intercomparing NDVI time series trend analysis consistency of Sahel from AVHRR GIMMS, Terra MODIS and SPOT VGT data, Remote Sens. Environ., 113, 1886-1898, 2009.

Hamon, W. R.: Computation of direct runoff amounts from storm rainfall, Int. Assoc. Sci. Hydrol. Publ., 63, 52-62, 1963.

He, X. B., Li, Z. B., Hao, M. D., Tang, K. L., and Zheng, F. L.: Downscale analysis for water scarcity in response to soil-water conservation on Loess Plateau of China, Agr. Ecosyst. Environ., 94, 355-361, 2003.

Hutchinson, M. F.: The application of thin plate smoothing splines to continent-wide data assimilation, in: BMRC Research Report No. 27, Data Assimilation Systems, edited by: Jasper, J. D., Bureau of Meteorology, Melbourne, 104-113, 1991.

Hutchinson, M. F. and Gessler, P. E.: Splines - more than just a smooth interpolator, Geoderma, 62, 45-67, 1994.

Li, Z., Liu, W. Z., Zhang, X. C., and Zheng, F. L.: Impacts of land use change and climate variability on hydrology in an agricultural catchment on the Loess Plateau of China, J. Hydrol., 377, 35-42, 2009.

Li, Z. C., Wei, Z. G., Wen, J., and Fu, R.: Analyses on climate variation characteristics over the Loess Plateau in recent 50 years, Journal of Arid Land Resources and Environment, 22, 57-62, 2008.

Ma, Z. M., Kang, S. Z., Zhang, L., Tong, L., and Su, X. L.: Analysis of impacts of climate variability and human activity on streamflow for a river basin in arid region of northwest China, J. Hydrol., 352, 239-249, 2008.

McVicar, T. R., Li, L. T., Van Niel, T. G., Zhang, L., Li, R., Yang, Q. K., Zhang, X. P., Mu, X. M., Wen, Z. M., Liu, W. Z., Zhao, Y. A., Liu, Z. H., and Gao, P.: Developing a decision support tool for China's re-vegetation program: Simulating regional impacts of afforestation on average annual streamflow in the Loess Plateau, Forest Ecol. Manag., 251, 65-81, 2007.

$\mathrm{Mu}$, Q., Heinsch, F. A., Zhao, M., and Running, S. W.: Development of a global evapotranspiration algorithm based on MODIS and global meteorology data, Remote Sens. Environ., 111, 519-536, 2007.

Palmroth, S., Katul, G. G., Hui, D., McCarthy, H. R., Jackson, R. B., and Oren, R.: Estimation of long-term basin scale evapotranspiration from streamflow time series, Water Resour. Res., 46,
W10512, doi:10.1029/2009WR008838, 2010.

Potter, N. J., Zhang, L., Milly, P. C. D., McMahon, T. A., and Jakeman, A. J.: Effects of rainfall seasonality and soil moisture capacity on mean annual water balance for Australian catchments, Water Resour. Res., 41, W06007, doi:10.1029/2004WR003697, 2005.

Price, K. C., Jackson, R., Parker, A. J., Reitan, T., Dowd, J., and Cyterski, M.: Effects of watershed land use and geomorphology on stream low flows during severe drought conditions in the southern Blue Ridge Mountains, Georgia and North Carolina, United States, Water Resour. Res., 47, W02516, doi:10.1029/2010WR009340, 2011.

Sun, G., Zhou, G. Y., Zhang, Z. Q., Wei, X. H., McNulty, S. G., and Vose, J. M.: Potential water yield reduction due to forestation across China, J. Hydrol., 328, 548-558, 2006.

Sun, G., Alstad, K., Chen, J. Q., Chen, S. P., Ford, C. R., Lin, G. H., Liu, C. F., Lu, N., McNulty, S. G., Miao, H. X., Noormets, A., Vose, J. M., Wilske, B., Zeppel, M., Zhang, Y., and Zhang, Z. Q.: A general predictive model for estimating monthly ecosystem evapotranspiration, Ecohydrology, 4, 245-255, 2011 a.

Sun, G., Caldwell, P., Noormets, A., Cohen, E., McNulty, S. G., Treasure, E., Domec, J.-C., Mu, Q., Xiao, J., John, R., and Chen, J.: Upscaling Key Ecosystem Functions across the Conterminous United States by a Water-Centric Ecosystem Model, J. Geophys. Res., 116, G00J05, doi:10.1029/2010JG001573, 2011 b.

Wahba, G. and Wendelberger, J.: Some new mathematical methods for variational objective analysis using splines and crossvalidation, Mon. Weather Rev., 108, 1122-1145, 1980.

Wang, S. P., Zhang, Z. Q., Sun, G., McNulty, S. G., and Zhang, M. L.: Detecting water yield variability due to the small proportional land use and land cover changes in a watershed on the Loess Plateau, China, Hydrol. Process., 23, 3083-3092, 2009.

Wang, Y. H., Yu, P., Feger, K. H., Wei, X., Sun, G., Bonell, M., Xiong, W., Zhang, S., and Xu, L.: Annual runoff and evapotranspiration of forestlands and non-forestlands in selected basins of the Loess Plateau of China, Ecohydrol., 4, 277-287, 2011.

Wang, Y. R.: Warming and frought response of Autumn climate over Loess Plateau to global warm, Plateau Meteorol., 27, 104 112, 2008.

Wattenbach, M., Zebisch, M., Hattermann, F., Gottschalk, P., Goemann, H., Kreins, P., Badeck, F., Lasch, P., Suckow, F., and Wechsung, F.: Hydrological impact assessment of afforestation and change in tree-species composition - a regional case study for the federal state of Brandenburg (Germany), J. Hydrol., 346, 1-17, 2007.

Wei, X., Sun, G., Vose, J., Otsuki, K., Zhang, Z., and Smetterm, K.: Preface. Forest ecohydrological processes in a changing environment, Ecohydrology, 4, 143-145, 2011.

$\mathrm{Xu}, \mathrm{J}$. and Cao, Y.: Efficiency and sustainability of converting cropland to forest and grassland in the western region, in: Implementing the Natural Forest Protection Programand the Sloping Land Conversion Program: Lessons and Policy Implications, edited by: Xu, J., Katsigris, E., and White, T. A., CCICED-WCFGTF, China Forestry Publishing House, Beijing, 2002.

Zhang, B. Q., Wu, P., and Zhao, X. N.: Detecting and analysis of spatial and temporal variation of vegetation cover in the Loess Plateau during 1982-2009, Trans. CSAE, 27, 287-293, 2011.

Zhang, L., Dawes, W. R., and Walker, G. R.: Response of mean annual evapotranspiration to vegetation changes at catchment scale, 
Water Resour. Res., 37, 701-708, 2001.

Zhang, L., Hickel, K., Dawes, W. R., Chiew, F. H. S., Westem, A. W., and Briggs, P. R.: A rational function approach for estimating mean annual evapotranspiration, Water Resour. Res., 40, W02502, doi:10.1029/2003WR002710, 2004.

Zhang, X. P., Zhang, L., McVicar T. R., Van Niel, T. G., Li, L. T., Li, R., Yang, Q. K., and Wei, L.: Modelling the impact of afforestation on average annual streamflow in the Loess Plateau, Chin. Hydrol. Process., 22, 1996-2004, 2008a.

Zhang, X. P., Zhang, L., Zhao, J., Rustomji, P., and Hairsine, P.: Responses of streamflow to changes in climate and land use/cover in the Loess Plateau, China, Water Resour. Res., 44, W00A07, doi:10.1029/2007WR006711, 2008b.

Zhang, W. C., Zhong, S., and Hu, S. Y.: Spatial scale transferring study on Leaf Area Index derived from remotely sensed data in the Heihe River Basin, China, Acta Ecol. Sin., 28, 2495-2503, 2008c. (in Chinese)

Zhou, G. Y., Wei, X. H., Luo, Y., Zhang, M. F., Li, Y. L., Qiao, Y., Liu, H. G., and Wang, C. L.: Forest recovery and river discharge at the regional scale of Guangdong Province, China, Water Resour. Res., 46, W09503, doi:10.1029/2009WR008829, 2010. 